\title{
'The Good Shepherd Lays Down His Life for the Sheep' (John 10:11, 15, 17): Questioning the Limits of a Johannine Metaphor
}

Christopher W. Skinner

Loyola University Chicago, cskinner1@luc.edu

Follow this and additional works at: https://ecommons.luc.edu/theology_facpubs

Part of the Religious Thought, Theology and Philosophy of Religion Commons

\section{Recommended Citation}

Skinner, Christopher W.. 'The Good Shepherd Lays Down His Life for the Sheep' (John 10:11, 15, 17): Questioning the Limits of a Johannine Metaphor. Catholic Biblical Quarterly, 80, 1: 97-113, 2018. Retrieved from Loyola eCommons, Theology: Faculty Publications and Other Works,

This Article is brought to you for free and open access by the Faculty Publications and Other Works by Department at Loyola eCommons. It has been accepted for inclusion in Theology: Faculty Publications and Other Works by an authorized administrator of Loyola eCommons. For more information, please contact ecommons@luc.edu.

\section{(c) $($ ) $\Theta(-)$}

This work is licensed under a Creative Commons Attribution-Noncommercial-No Derivative Works 3.0 License. (C) Catholic Biblical Association 2018 


\title{
"The Good Shepherd Lays Down His Life for the Sheep" (John 10:11, 15, 17): Questioning the Limits of a Johannine Metaphor
}

\author{
CHRISTOPHER W. SKINNER \\ Loyola University Chicago \\ Chicago, IL 60660
}

\begin{abstract}
Scholars have long recognized that the Good Shepherd discourse reflects a realistic picture of the ancient Palestinian shepherd and his relationship to the flock. But how far should the details in this metaphor be pressed? It is often asserted that any halfway decent shepherd would have been willing to die on behalf of his flock and that Jesus' statement to that effect $(10: 11,15,17)$ reflects a common expectation. This scenario, however, would actually leave a flock more exposed to danger. Thus, it is appropriate to understand Jesus' pronouncement as falling outside the realm of historical verisimilitude and better to regard the "laying down of the shepherd's life" as the singular element of the discourse that is intended to advance the story's christological agenda.
\end{abstract}

Key Words: shepherd • metaphor • verisimilitude $\cdot$ Gospel $・$ John $・$ paroimia

SHEPHERD IMAGERY IS UBIQUITOUS in the writings of classical and late antiquity. Reflections on the life and vocation of the shepherd seem to have been commonplace among ancient writers; this is especially true among the so-called Greek

I would like to thank Dr. Francis J. Moloney, S.D.B., who read an earlier version of this manuscript and offered numerous suggestions for improvement. I would also like to thank my colleague at Loyola University Chicago Dr. Devorah Schoenfeld for her assistance in helping me round out several footnotes with the most appropriate citations of Jewish literature. A previous version of this paper was presented to the John and Old Testament Taskforce of the Catholic Biblical Association in August 2017. I wish to thank the members of the group who provided helpful feedback and editorial comments. 
bucolic poets-Theocritus (d. 261 B.C.E.), Bion (121- 51 B.C.E.), and Moschus (second century B.C.E.) - along with Virgil (70-19 B.C.E.) who wrote in Latin. ${ }^{1}$ Their writing usually depicted idyllic scenery and often included a protracted lament or dirge. It goes without saying that we also have an abundance of shepherdsheep imagery in the sacred writings of both Judaism and Christianity. In various passages of the Hebrew Bible, Yhwh is pictured as shepherd, while his people are depicted as sheep $;{ }^{2}$ and the leaders of Israel are the shepherds (commonly depicted as failing at the task), while the nation is represented by the image of a flock. ${ }^{3}$ Other Jewish texts reflect the more ordinary roles or commonplace position that shepherds held in everyday life. ${ }^{4}$ Additionally, some early Christian texts picture the $\pi \rho \varepsilon \sigma \beta \dot{v} \tau \varepsilon \rho o$ serving as the shepherds and the church members as sheep. ${ }^{5}$ In the NT, shepherd imagery - though less frequent - is quite important by comparison, especially when such imagery is applied to Jesus and his followers. The present article is concerned with one such example.

The evidence cited above suggests that shepherding was a familiar profession in ancient agrarian societies and was unremarkable by comparison with other professions. There can be little doubt that such familiarity contributed to the realism of biblical shepherding scenes among early audiences, even when shepherd-sheep imagery appeared in the context of metaphorical depictions, as it does in John 10:1-21, the so-called Good Shepherd discourse. ${ }^{6}$ Commentators often assert that

${ }^{1}$ See The Greek Bucolic Poets (trans. J. M. Edmonds; LCL; New York: Macmillan, 1912). On the significance of these poets for the development of pastoral poetry in the eighteenth and nineteenth centuries, see Wilfred P. Mustard, "The Pastoral-Ancient and Modern," Classical Weekly 21 (1915) 161-67.

${ }^{2}$ E.g., Gen 48:15; 49:24; Pss 23:1-4; 28:9; 79:13; 80:1; Isa 40:10-11; Jer 31:10; Ezek 34:1-31; Zech $9: 16 ; 11: 4-17$.

${ }^{3}$ E.g., 2 Sam 5:2; 7:7; 24:17; 1 Kgs 22:17; 1 Chr 11:2; 17:6; 21:17; Ps 78:70-72; Isa 44:28; 56:11; Jer $3: 15 ; 23: 1-4 ; 25: 34-36 ; 50: 6 ;$ Zech 10:2-3; 13:7.

${ }^{4}$ Among others, see $m$. Pes. 8:2; m. Beșah 5:3; m. Yeb. 7:1; m. B. Qam. 6:2; m. Hul. 4:3; b. Shab. 32a, 53b, 62a, 148b; b. Yoma 66b, 83b; b. Beșah 25b, 29b, 37a, 37b, 38a, 40a.

${ }^{5}$ In his Epistle to the Philadelphians, Ignatius of Antioch writes, "Therefore, as children of the light of truth, flee from division and false teaching. Where the shepherd is, there follow like sheep. For many seemingly trustworthy wolves attempt, by means of wicked pleasure, to take captive the runners in God's race; but in your unity they will find no opportunity" (2:1-2) (Michael W. Holmes, ed., The Apostolic Fathers: Greek Texts and English Translations [Grand Rapids: Baker Academic, 2007] 239; emphasis added). We also see appropriations of Zech 13:7 ("strike the shepherd and the sheep will scatter") in early Christian literature; see, e.g., Barn. 5:12; Justin Dial. 53:5-6.

${ }^{6}$ It is commonly asserted that the Fourth Gospel has no narrative parables like those we see in abundance in the Synoptics. Jesus' raporuia in John 10, however, is the closest example we have in the Fourth Gospel and has regularly been categorized as a משל (māšăl). I discuss the relationship

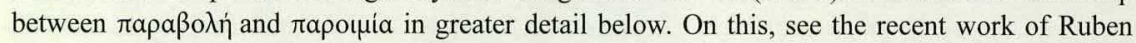
Zimmermann, who argues against the notion that there are no true parables in the Fourth Gospel (Puzzling the Parables of Jesus: Methods and Interpretation [Minneapolis: Fortress, 2015] 333-60). 
the entire scene, although possessing an allegorical character, is infused with verisimilitude, which would have made it immediately understandable to a first-century audience. In what follows, I want to begin by undertaking an exegesis of the text, with specific emphasis upon the imagery employed in Jesus' "figure of speech" (rapotpia) in John 10. In the light of that imagery, I want to examine the realism of the scene against the backdrop of common scholarly assertions about the verisimilitude of its various elements. Finally, I will examine the "laying down" of the shepherd's life (vv. 11, 15, 17), which is more than a simple risking of one's life but is a transparent way of speaking about death. Against that backdrop, I will challenge the assertion that this "laying down" would have been a realistic expectation, and I will argue that this element of the discourse extends the metaphor of the good shepherd by introducing an extraordinary quality rooted in a uniquely Johannine christological emphasis.

Before we go further we need to touch briefly on the nature of Jesus' $\pi \alpha \rho \circ \mu i \alpha$ in John 10, which closely resembles numerous features of the Synoptic parables. ${ }^{7}$

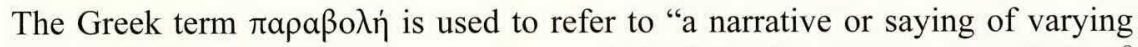
length, designed to illustrate a truth especially through comparison or simile." Other glosses include "illustration," "proverb," and "maxim." Параßо $\lambda$ ' is the term most commonly used to translate the Hebrew term which is properly understood as a "similitude," "by-word," "prophetic figurative discourse," or moral story with allegorical features. ${ }^{10} \mathrm{~A}$ משל "generally considers two things side by side for the sake of comparison. ${ }^{11}$ Similarly, $\pi \alpha \rho o$ pia is defined as "a brief communication containing truths designed for initiates," and glosses include "veiled saying" and "figure of speech in which lofty ideas are concealed."12 Given these similarities, we should not be surprised that there are instances where $\pi \alpha \rho \alpha \beta 0 \lambda \eta \dot{~ a n d ~ \pi \alpha \rho o н \mu i \alpha ~ a r e ~ u s e d ~ i n t e r c h a n g e a b l y ~(e . g ., ~ S i r ~ 47: 17) ~ a s ~ w e l l ~ a s ~}$

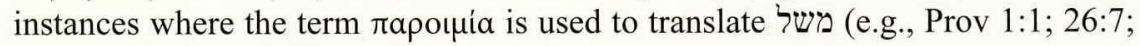
Sir $6: 35 ; 8: 8 ; 18: 29 ; 39: 3 ; 47: 17)$. While it would be a mistake to equate $\pi \alpha \rho a \beta o \lambda \eta ́$

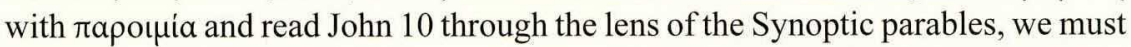
be aware of the allegorical elements present in the images of both the door to the

\footnotetext{
${ }^{7}$ See the helpful treatment of the distinctions between $\pi \alpha \rho \alpha \beta o \lambda \dot{\eta}$ and $\pi \alpha \rho o u \mu$ in Karoline M. Lewis, Rereading the "Shepherd Discourse": Restoring the Integrity of John 9:3910:21 (Studies in Biblical Literature 113; New York: P. Lang, 2008) 2-7. See also Uta Poplutz, "Paroimia und Parabole: Gleichniskonzepte bei Johannes und Markus," in Imagery in the Gospel of John: Terms, Forms, Themes, and Theology of Johannine Figurative Language (ed. Jörg Frey, Jan G. van der Watt, and Ruben Zimmermann; WUNT 200; Tübingen: Mohr Siebeck, 2006) 103-20.

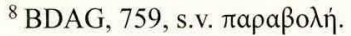

${ }^{9}$ Ibid.

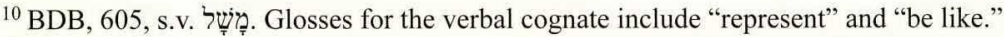

${ }^{11}$ For more on the etymology and background of the term, see Paul Haupt, "Hebrew Mašál," JBL 36 (1917) 40-42; and Allen Howard Godbey, "The Hebrew Mašál," AJSL 39 (1923) 89-108.

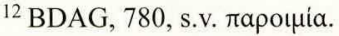


sheep pen (vv. 1-10) and the good shepherd (vv. 11-18). At the very least, we need to be mindful that the discourse is asking the reader "implicitly or explicitly to make a comparison in each of the figures of the passage. The reader is asked to compare Jesus with the entry to the sheepfold, with the shepherd who tends and cares for the sheep, and with the obedient child of a loving parent." 13 Thus, although we are not dealing with the generic form of Jesus' teaching that is identical to that in the Synoptics, we should proceed with an awareness of the similarities between

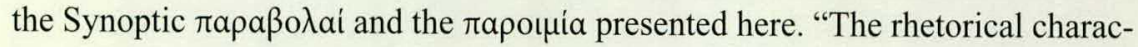

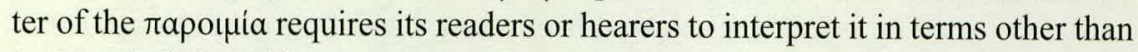
its literal claim. This requirement applies not only to Jesus' interlocutors in the Gospel narrative (who regularly misunderstand him) but also to the audience of the Gospel itself." ${ }^{14}$ We turn now to an exegesis of the Good Shepherd discourse.

\section{The Good Shepherd Discourse (John 10:1-21)}

A great deal has been written exploring the shepherd imagery behind John $10 .{ }^{15}$ While some of this material has emphasized potential connections to ancient Greco-Roman rhetoric, ${ }^{16}$ most studies have concentrated on shepherding images found in Ezekiel 34, Zechariah 9-14, and Psalm 23. ${ }^{17}$ For the purposes of this

${ }^{13}$ Robert Kysar, "Johannine Metaphor-Meaning and Function: A Literary Case Study of John 10:1-8," in The Fourth Gospel from a Literary Perspective (ed. R. Alan Culpepper and Fernando F. Segovia; Semeia 53; Atlanta: Scholars Press, 1991) 81-111, here 96.

${ }^{14}$ William M. Wright, "Hearing the Shepherd's Voice: The $\pi \alpha \rho o u i \alpha$ of the Good Shepherd Discourse and Augustine's Figural Reading," Journal of Theological Interpretation 6 (2012) $97-116$, here 103 .

${ }^{15}$ See, e.g., Ruben Zimmermann, "Jesus im Bild Gottes: Anspielungen auf das Alte Testament im Johannesevangelium am Beispiel der Hirtenbildfelder in Joh 10," in Kontexte des Johannesevangeliums: Das vierte Evangelium in religions- und traditionsgeschichtlicher Perspektive (ed. Jörg Frey and Udo Schnelle; WUNT 2/175; Tübingen: Mohr Siebeck, 2004) 81-116; Joachim Kugler, "Der andere König: Religionsgeschichtliche Anmerkungen zum Jesusbild des Johannesevangeliums," $Z N W 88$ (1997) 223-41; Donald L. Fowler, "The Background to the Good Shepherd Discourse in John 10," in New Testament Essays in Honor of Homer A. Kent, Jr. (ed. Gary T. Meadors; Winona Lake, IN: BMH Books, 1991) 143-63; J. Duncan M. Derrett, "The Good Shepherd: St. John's Use of Jewish Halakah and Haggadah," ST 27 (1973) 25-30; John Quasten, "The Parable of the Good Shepherd: Jn. 10:1-21," CBQ 10 (1948) 151-69; B. W. Bacon, "Pauline Elements in the Fourth Gospel: Parables of the Shepherd, John X.1-39," ATR 11 (1929) 305-20. See also the overview in Andreas J. Köstenberger, "Jesus the Good Shepherd Who Will Also Bring Other Sheep (John 10:16): The Old Testament Background of a Familiar Metaphor," BBR 12 (2002) 67-96; and several chapters in Johannes Beutler and Robert T. Fortna, eds., The Shepherd Discourse of John 10 and Its Context (SNTSMS 67; Cambridge: Cambridge University Press, 1991).

${ }^{16}$ See, e.g., Jerome H. Neyrey, "The 'Noble Shepherd' in John 10: Cultural and Rhetorical Background," JBL 120 (2001) 267-91; idem, “'I Am the Door' (John 10:7, 9): Jesus the Broker in the Fourth Gospel," CBQ 69 (2007) 271-91.

${ }^{17}$ See, e.g., Mary Katharine Deely, “Ezekiel's Shepherd and John's Jesus: A Case Study in 
article, I assume that such images, and most likely a conflated picture drawn from these texts, informed Jewish thinking about shepherding within religious contexts. I will not speculate here on which specific passage(s) are operative as intertexts as it would take us too far afield of the present argument. Suffice it to say that the picture of a good shepherd in John 10 is infused with imagery drawn largely from the Hebrew Bible.

The biblical images of shepherds are often positive, though in some segments of Jewish society shepherding was not always regarded as the noblest of professions. ${ }^{18}$ In this passage, however, Jesus precludes any such objection by explicitly referring to himself as the good shepherd (vv. 11, 14). Our brief exegesis will divide this discourse into the following four sections:

1. Thief or Shepherd? (vv. 1-6)

2. Jesus, the Door for the Sheep (vv. 7-10)

3. Jesus, the Good Shepherd (vv. 11-18)

4. Division over Jesus' Teaching (vv. 19-21)

Before embarking on an exegesis of the text, we should acknowledge that our present chapter divisions are artificial and that even though John 10:1-21 represents a coherent unit of literary thought, it should properly be understood as Jesus' response to the division that has just occurred over the healing of the man born blind in chap. 9. The situation depicted in 9:35-41 contrasts the sight of the man who was previously blind with the spiritual blindness of the Pharisees, who claim to be able to see. John 10:1-21 thus provides further commentary on why the Pharisees are unfit to lead and contrasts Jesus, the gate for the sheep and the good shepherd, with the Pharisees, whom he has just characterized as blind. In what is clearly a figure of speech, Jesus describes himself in metaphorical terms that are

the Appropriation of Biblical Texts," in Early Christian Interpretation of the Scriptures of Israel: Investigations and Proposals (ed. Craig A. Evans and James A. Sanders; JSNTSup 148; Sheffield: Sheffield Academic, 1997) 252-64; Brian Neil Petersen, John's Use of Ezekiel: Understanding the Unique Perspective of the Fourth Gospel (Minneapolis: Fortress, 2015) 133-50. See also Basilius Ebel, "Das Bild des Guten Hirten im 22. Psalm nach Erklärungen der Kirchenväter," in Universitas: Dienst an Wahrheit und Leben. Festschrift für Bischof Dr. Albert Stohr im Auftrag der KatholischTheologischen Fakultät der Johannes Gutenberg-Universität Mainz (ed. Ludwig Lenhard; 2 vols.; Mainz: M. Gruenewald, 1960) 1:48-57.

${ }^{18}$ See, e.g., the Mishnah's description of the shepherding as a "thief's profession" ( $m$. Qidd. 4:13-14). Further, in m. B. Qam. 6:1-3 we read of penalties and exemptions for damages caused by flocks grazing on the land of others, an offense tantamount to theft. By contrast, Gerald Aranoff suggests that Abel, the first biblical example of a righteous shepherd, invests the shepherd symbol with nobility: "Emphasizing that many biblical heroes were shepherds is, fundamentally, a way of categorizing them as holy-individuals who were, in practice, capable of bringing the right kind of offering to God" ("Shepherding as a Metaphor," Jewish Bible Quarterly 42 [2014] 36-38, here 38). 
meant to draw a contrast between himself and the Pharisees. These insights will guide our exegesis of the discourse.

\section{A. Thief or Shepherd? (10:1-6)}

On the heels of the controversy over Jesus' healing of the man born blind (9:25-41), v. 1 begins with a characteristically Johannine double ả $\mu \eta \dot{v}$ statement that, in the immediate literary context, connects to 9:41, where Jesus tells the Pharisees: "If you were blind, you would not have sin. But now that you say, 'We see,' your sin remains." Drawing an example from the everyday experience of shepherding life, Jesus turns his attention to the pen (aủํ) in which sheep are kept. Those who enter the pen by some means other than the door (or "gate," $\theta \dot{v} \rho \alpha$ ) are thieves and robbers (v. 1). By contrast, the one who either enters directly through the gate (v. 2) or is permitted to enter by means of a gatekeeper (v. 3 ) is the shepherd, who calls the sheep by name and is authorized to lead them out into pasture.

Once the shepherd leads the sheep out of the pen into the pasture, they follow him because they know (or perhaps "recognize," ot $\delta \alpha \sigma v$ ) the sound of his voice (v. 4), but the sheep will be frightened by the voice of a run-of-the-mill stranger (v. 5). While it is clear that Jesus is speaking allegorically, it is not yet clear what his point is. In a final comment in this first section-which is reminiscent of a common response to the parabolic preaching of Jesus in his Synoptic iterationsthe narrator notes that, when Jesus spoke this rapoupia to the gathered group, they were not able to understand him (v. 6). ${ }^{19}$ At least four elements of this depiction of the shepherd-sheep relationship require further exploration before we move ahead.

First, as Kenneth E. Bailey notes, a Middle Eastern shepherd was particularly vulnerable to two common external threats: thieves (individuals and gangs) and wild animals. ${ }^{20}$ Both threats are mentioned in this discourse: in v. 1 (cf. also vv. 8,

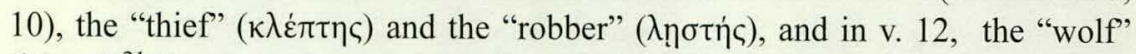

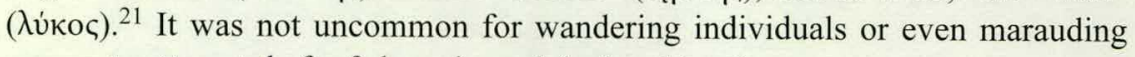
groups to attempt theft of sheep in such isolated locales.

${ }^{19}$ Cf., e.g., Mark 4:13; 8:31-32; 9:32; Matt 16:11; Luke 2:50; 9:45; 18:34.

${ }^{20}$ Kenneth E. Bailey, The Good Shepherd: A Thousand-Year Journey from Psalm 23 to the New Testament (Downers Grove, IL: IVP Academic, 2014) 211.

${ }^{21}$ The terms $\kappa \lambda \dot{\varepsilon} \pi \tau \eta \varsigma$ and $\lambda \eta \emptyset \sigma \eta \dot{\varsigma}$ have distinct but overlapping semantic domains. K $\lambda \dot{\varepsilon} \pi \tau \eta \varsigma$ properly refers to one who steals (cf. the verb $\kappa \lambda \dot{\varepsilon} \pi \tau \omega$, "to steal") while $\lambda$ nø $\sigma \dot{\zeta} \varsigma$ is used either to denote a "robber, highwayman, bandit," or "revolutionary, insurrectionist" (BDAG, 594). Despite these different glosses, the two terms appear to be used interchangeably here, though J. B. Souček suggests that "Palestinian usage [of $\lambda \eta \sigma \tau \dot{\zeta}$ ] of the first century suggests the various political messiahs who abounded in the excited atmosphere around the great Jewish war" ("The Good Shepherd and His Flock," Ecumenical Review 9 [1957] 143-53, here 149). See also the intriguing 
Second, it is important to our apprehension of this raporpia to understand the

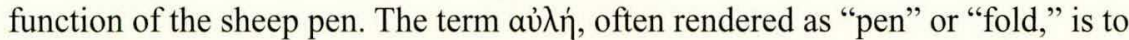
be understood as "an area open to the sky" or an "enclosed open space." ${ }^{22}$ Craig S. Keener notes how the enclosures took several different forms while sharing some common features, including both an open roof and doorway. ${ }^{23}$ Again we turn to Bailey for a description of the structure:

For centuries shepherds have constructed round, roughly built enclosures in the wilderness, using uncut field stones. Once again thorns (if available) are worked into the top of the wall, and the herd that arrives first is free to shelter for the night in any one of these freestanding stone structures that have no roofs or doors. The only vulnerable spot, once the sheep are inside the sheepfold, is across the entrance. ${ }^{24}$

Thus, the sheep pen was a picture of both exposure and vulnerability, and this is at least one reason why it is necessary to have a capable, diligent shepherd. In addition, the entrance — which most commonly lacked a door — will help us make sense of Jesus' grandiose, though somewhat confusing claim in v. 7.

Third, we turn to the question of a "gatekeeper" ( $\theta v \rho \omega \rho$ ó $\varsigma)$, about which there is mostly speculation but no real clarity. Many modern commentators refer to this individual as some sort of under-shepherd or "porter," but this element of Jesus'

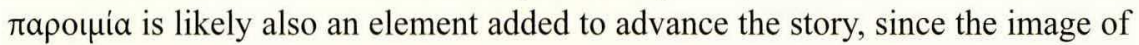
the shepherd himself as the "door for the sheep" will emerge in the very next section of the discourse (see v. 7). ${ }^{25}$ If the open enclosure is anything like what was described above, then the presence of a gatekeeper was probably only a luxury for those with exceptionally large flocks entering pens with some sort of gate affixed

thesis of A. J. Simonis, who sees, among other textual elements, aủㄲ

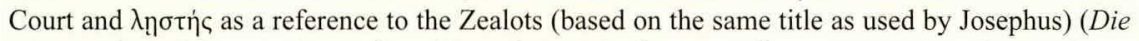
Hirtenrede im Johannes-Evangelium: Versuch einer Analyse von Johannes 10, I-18nach Entstehung, Hintergrund, und Inhalt [AnBib 29; Rome: Biblical Institute Press, 1967]).

${ }^{22}$ BDAG, 150, s.v. aủì.

${ }^{23}$ Craig S. Keener, The Gospel of John: A Commentary (2 vols.; Peabody, MA: Hendrickson, 2003) $1: 809$.

${ }^{24}$ Bailey, Good Shepherd, 222

${ }^{25}$ E.g., Andrew T. Lincoln, The Gospel according to St. John (BNTC 4; Peabody, MA: Hendrickson, 2005) 293; Francis J. Moloney, Signs and Shadows: Reading John $5-12$ (Minneapolis: Fortress, 1996) 131; D. A. Carson, The Gospel according to John (Pillar New Testament Commentary; Grand Rapids: Eerdmans, 1990) 381; Xavier Léon-Dufour, Lecture de l'évangile selon Jean (4 vols.; Parole de Dieu; Paris: Seuil, 1990) 2:360; C. K. Barrett, The Gospel according to St. John: An Introduction with Commentary and Notes on the Greek Text (2nd ed.; Philadelphia: Westminster, 1978) 369. By contrast, J. Ramsey Michaels notes that the "presence of a 'doorkeeper' is the only hint in the text that other shepherds may have their sheep within the courtyard, but this detail is more likely just part of what a reader might have visualized as a normal courtyard setting (see 18:15-17)" (The Gospel of John [NICNT; Grand Rapids: Eerdmans, 2010] 578). 
to the structure. ${ }^{26}$ In most instances, these enclosures were probably lacking both a permanent door and a gatekeeper.

Fourth, we need to look more closely at Jesus' assertion that the sheep recognize the voice of the shepherd but flee at the voice of the stranger. A common practice among shepherds was the ascription of names to various sheep within the flock, often based on some distinguishing characteristic, including shape and size. More diligent shepherds would make it a point to count their sheep and use fixed ways of summoning them, not only calling them by a given name but also by means of a whistle. These forms of beckoning the sheep would have been recognizable to the flock and would have signaled the shepherd's presence. At the allegorical level, Jesus is using this as a description of his familiarity with and perhaps affection for his followers; this interpretation will be confirmed by his later statement in 10:27: "My sheep hear my voice, and I know them and they follow me." Again, we need to keep in mind that this raporpia is intended to contrast Jesus, who is fit to lead, with the Jewish leaders, who are not.

\section{B. Jesus, the Gate for the Sheep (vv. 7-10)}

As in v. 1, this section of the discourse begins with another double áuńv statement: "Amen amen I say to you, 'I am the door for the sheep"' (v. 7). This somewhat cryptic proclamation follows the Pharisees' inability to understand what Jesus has just said, thus potentially confounding them even further. Here the double áun vis combined with another distinctive element of Johannine discourse, the

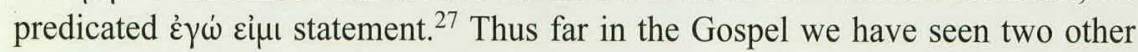

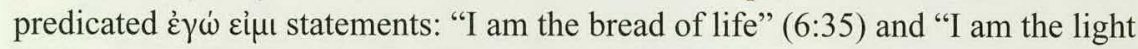
of the world" (8:12). Here in this section of the discourse we encounter the third such pronouncement, followed in the next section by the fourth. Jesus will at first identify himself as the door for the sheep $(10: 7,9)$, and in the next section as the good shepherd $(10: 11,14)$. Although the Gospel has provided one other example

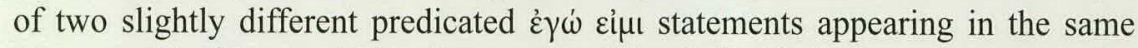
discourse (the Bread of Life discourse in John 6), ${ }^{28}$ this is the only place in the

\footnotetext{
${ }^{26}$ Keener discusses instances in which either a roof, a door, or both were affixed to certain enclosures (Gospel of John, 1:809).

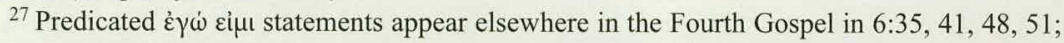
$8: 12 ; 11: 25 ; 14: 6 ; 15: 1,5$. Each predicate introduces a title that is reminiscent of an important image from Israel's story and has in view a connection to some important image or theme from Israel's Scriptures. On this, see David Mark Ball, 'I Am' in John's Gospel: Literary Function, Background, and Theological Implications (JSNTSup 124; Sheffield: Sheffield Academic, 1996).

${ }^{28}$ In 6:35, Jesus declares, "I am the bread of life"; then, in 6:41, he announces, "I am the bread which came down from heaven." Again in 6:48 he says, "I am the bread of life," followed in 6:51 by, "I am the living bread which came down from heaven." Despite their subtle differences, these two titles are obviously being used interchangeably.
} 
Fourth Gospel where two related $\varepsilon \gamma \omega \dot{\omega}$ ciu statements appear in the same unit and the second image departs markedly from the first. This difference also raises another difficulty for our interpretation of the passage - the role of a "gatekeeper" vis-à-vis Jesus' claim to be the "door."

In v. 3, Jesus referred to a gatekeeper ( $\theta v \rho \omega \rho$ ó $)$, who is regarded as some kind of under-shepherd and who was presumably responsible for opening the gate for the sheep to enter. Here, however, Jesus alters the scene. No longer is there a door to be opened by a cooperating shepherd. Instead, Jesus is the door. What exactly does this mean, especially in light of his earlier comment about the gatekeeper? ${ }^{29}$ Our previous discussion of sheep pens emphasized that most enclosures were lacking both a roof and a door. One way to ensure that sheep remained in the pen, especially overnight, was to have the shepherd lie across the open threshold, and thus literally serve as the door. ${ }^{30}$ The implied visual of shepherds lying over the opening to the enclosure in which the sheep were kept has a point of connection with and likely anticipates Jesus' announcement in v. 11 that he is the good shepherd.

In a thinly veiled critique of the Pharisees, Jesus says that all who have preceded him are thieves and robbers (v. 8), to which he has already alluded. These are the ones who enter the pen illegitimately and are not truly authorized to lead the flock (cf. v. 2). Jesus reiterates, "I am the door" (v. 9a). As the means by which the sheep (viz., the followers of God) enter and exit the pen, Jesus is the locus of

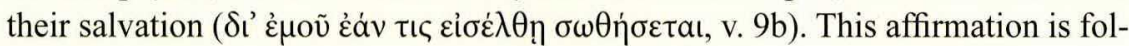
lowed by a particularly damning indictment of all who have preceded Jesus, but in the immediate context it is an indictment of the Pharisees, who are represented by the image of a "thief" ( $\kappa \lambda \dot{\varepsilon} \pi \tau \eta \varsigma)$. They hide behind noble intentions, but their

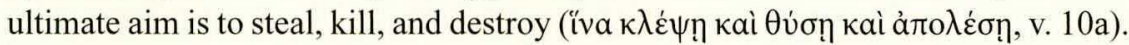
By contrast, Jesus aims to provide life and abundance for the sheep/followers of God. ${ }^{31}$

${ }^{29}$ Moloney plausibly explains the mixing of metaphors by arguing that the parable is intentionally developed in stages (Signs and Shadows, 133-35).

${ }^{30}$ Though he is not alone, Kenneth Bailey has been one of the chief sources for this interpretation. His work often looks to contemporary Bedouin practices for his historical reconstructions. While the evidence for this practice may not be as widely attested as we might wish, the practice does seem highly plausible in light of the many other features of ancient shepherding that are easily reconstructed. Further, it is essential to emphasize that one of the foundational insights advanced by social-scientific approaches to the NT is that Mediterranean cultural practices share a remarkable similarity across the centuries. Cultural anthropologists have observed consistency between ancient and modern Mediterranean cultures, arguing that they share a significant degree of "cultural compatibility" over a sustained period.

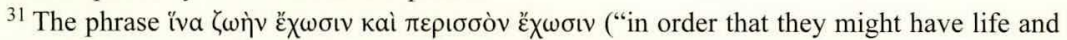
have abundance") may be hendiadys ("in order that they might have abundant life"). 


\section{Jesus, the Good Shepherd (vv. 11-18)}

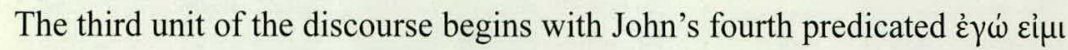
statement: "I am the good shepherd." This assertion makes much greater sense of the contrasts Jesus has been drawing between himself and the Pharisees and alters the metaphor introduced in vv. 7, 9. While the affirmation of Jesus as the good shepherd appears to be an example of mixing metaphors, it also makes perfect sense in the present context that a good shepherd would be the type of servant to lie across the threshold of an open enclosure and also literally serve as "the door." Despite the ways in which the image has been modified, we are still able to make sense of the intended contrasts between Jesus and the Pharisees.

As mentioned at the beginning of this article, there is much discussion among scholars as to the precise background for the image of a good shepherd. Here in the immediate context, where there exists a contrast between Jesus and the Pharisees, the question is about one's fitness to lead God's flock (or lack thereof). The image of shepherd, however, has been layered with deep and abiding messianic ideas in the writings of the Second Temple period. Francis J. Moloney notes that the "idea of one shepherd leading one people of God comes from the biblical tradition (see Mic 5:3-5; Jer 3:15; 23:4-6; Ezek 34:23-24) and continues to be used in later Jewish literature (see Psalms of Solomon 17:24, 40; CD 13:7-9; 2 Baruch 77:13-17). But there is newness in Jesus' linking his self-gift with the gathering of others into the one fold under the one shepherd." 32

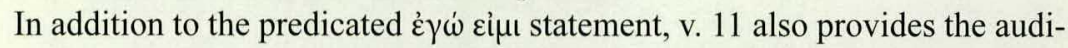
ence with the first of three assertions about the role of the shepherd in laying down

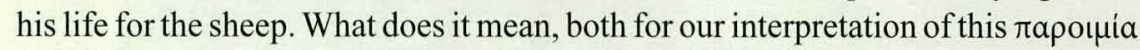
and for our wider understanding of Johannine christology, that the good shepherd willingly lays down his life on behalf of the sheep? Rudolf Bultmann has argued that the phrase "lay down one's life" ( life, to risk it, to be prepared to lay it down as in LXX Judg. 12.3; I Sam 19.5; 28.21." "33 Susan Hylen has also recently argued that the language of laying down one's life need not explicitly refer to death here but denotes the risking of one's

${ }^{32}$ Moloney, Signs and Shadows, 138.

${ }^{33}$ Rudolf Bultmann, The Gospel of John: A Commentary (trans. G. R. Beasley-Murray, R. W. N. Hoare, and J. K. Riches; Philadelphia: Westminster, 1971) 370 n. 5. Other commentators opt for a soft rendering here. For example, Michaels notes, "What makes a shepherd 'good' is that he 'lays down his life for the sheep,' that is, he puts his very life on the line to protect his flock" (Gospel of John, 585). Similarly, Marianne Meye Thompson comments, "Precisely because the shepherd faithfully guards his sheep, he puts himself in their place, willingly facing death so that they may live. The shepherd does so because the sheep belong to him $(10: 12,14)$ and he cares for them (v. 13): a hired hand has no vested interest in the sheep" (John: A Commentary [NTL; Louisville: Westminster John Knox, 2015] 226). 
life.$^{34}$ Given John's predilection for double meaning, such a translation is not outside the realm of possibility. Bultmann, however, argues that the phrase is to be read differently in v. 11 from its appearances in vv. 17 and following. Although Bultmann's attention to issues of grammar and syntax is unassailable, his method is necessarily limited by assumptions about the fragmentary nature of the text, and this often leads to conclusions that fail to consider the text's overall literary coherence. Practically, this means that Bultmann tends to draw grand conclusions without always paying careful attention to the literary dynamics that are in play. ${ }^{35}$ Additionally, although Hylen's reading of this shepherd metaphor as specifically related to how disciples are called to follow Jesus-and I do not dispute that such a theme could be present $-\mathrm{I}$ am focusing here on the fact that this passage is prin-

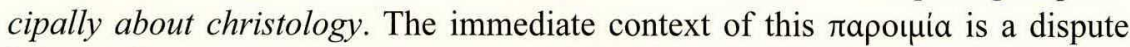
between Jesus and the Pharisees over who is fit to lead God's flock, and the pres-

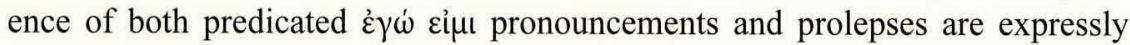
related to the Fourth Gospel's presentation of christology. ${ }^{36}$ Therefore, even if " $t 0$

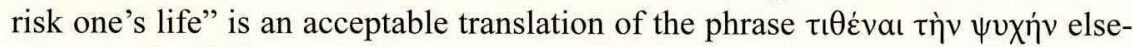
where in Greek literature, it does not capture the primary sense of the phrase used here or throughout the rest of the Fourth Gospel (cf., e.g., 13:37; 15:13).

This means that the primary sense of the phrase, "to lay down one's life" is directly related to the death of the shepherd, though at the literal level of a shepherd's job description, such a scenario seems both illogical and counterintuitive. Were the shepherd to die, either at the hands of a thief or from the attack of predatory animals, the flock would be even more exposed than before. A shepherd was known to have at least two protective instruments on his person-a rod to protect the flock from human or animal aggression, and a staff to maintain order within the flock. ${ }^{37}$ Bailey notes that the staff (שבט) is not a walking stick but "is

${ }^{34}$ Susan E. Hylen, "The Shepherd's Risk: Thinking Metaphorically with John's Gospel," BibInt 24 (2016) 382-99.

${ }^{35}$ I do not intend this critique to be anachronistic. I recognize that Bultmann's brilliant, epochmaking commentary was written while form criticism and its attendant assumptions reigned within NT scholarship, all of which predated narrative criticism by at least four decades. Having said that, however, it is also important for me to note that I assume the literary coherence of the text and am concerned with the narrative christological elements expressed throughout the final form of the Fourth Gospel. The present argument errs on the side of seeing a unified text, despite the presence of literary seams and other evidence suggesting the development of the text over time. For a more recent example of an approach to the text that emphasizes disunity rather than unity of any kind, see Urban C. von Wahlde, The Gospel and Letters of John (3 vols.; ECC; Grand Rapids: Eerdmans, 2010).

${ }^{36}$ For more on the christological significance of Johannine prolepses, see Adele Reinhartz, "Jesus as Prophet: Predictive Prolepses in the Fourth Gospel," JSNT 36 (1989) 3-16; also helpful is Gilbert Van Belle's analysis of prolepsis as a feature of Johannine style; see his "Prolepsis in the Gospel of John," NovT 43 (2001) 334-47.

${ }^{37}$ See Edmond Power, "The Shepherd's Two Rods in Modern Palestine and in Some Passages 
the shepherd's primary offensive weapon for protecting the flock from enemies, be they wild animals or human thieves." ${ }^{38} \mathrm{He}$ suggests that some shepherds additionally carried a sling. In this light, the "laying down of the shepherd's life" seems a last resort rather than a modus operandi and certainly does not appear to be voluntary. Conversely, the Johannine Jesus has come for the express purpose of voluntarily laying down his life.

Here is where we begin to distance ourselves from assigning a one-to-one correspondence between features of this rapoupia and the everyday realities of shepherding. In the immediate context of the discourse, for the shepherd to "lay down his life" is to willingly subject himself to death. Insofar as some form of this claim will appear four times in this section (vv. 11, 15, 17, 18), the laying down of the shepherd's life is a, if not the, key theme as it relates to the vocation and character of this metaphorical good shepherd. Others who have placed themselves in the role of shepherd have come, among other reasons, to kill (cf. v. 10). By contrast, it is the aim of the good shepherd to die. If this is the case, the text acts as a proleptic anticipation of the Johannine passion.

The presence in the story of a hired hand ( $\mu \iota \sigma \theta \omega \tau$ tó, v. 12a) who abandons the sheep at the sign of danger, functions in much the same way as the gatekeeper of v. 3. This hypothetical "hired hand" is a prop that moves the story along and creates space for another contrast with Jesus. ${ }^{39}$ In addition, other figures mentioned

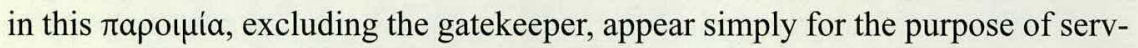
ing as foils for Jesus. The thieves and robbers enter the pen illegitimately, while Jesus is recognized by the under-shepherd and allowed entry (vv. 1-3). The voice of the stranger rattles the sheep, but they respond favorably to Jesus' voice (vv. 4-5). And now here we have a hired hand who is not vested in the well-being of the flock and therefore fails to provide necessary care in the face of an imminent attack by wolves (vv. 12b-13). It may also be the case that the wolf ( $\lambda$ ќко) symbolizes the predatory nature of the Pharisees, though we might be stretching the metaphor a bit. Such an interpretation, however, is not unlikely, given the narrator's tendency, in evidence here, to mix metaphors. In the context of this quasi-parabolic speech, each of these negative depictions is somehow emblematic of the Pharisees, with whom Jesus is in conflict.

of the Old Testament," Bib 9 (1928) 434-42. Psalm 23 speaks of the shepherd's "rod and the staff" (שבטך ומשענתך), while Zech 11:7 metaphorically depicts the shepherd's two staffs (שנים), one מקלות), called "graciousness" (נעם) and the other called "binders" (חבלים).

${ }^{38}$ Bailey, Good Shepherd, 50 (emphasis added).

${ }^{39}$ Keener comments, “The 'hirelings' (10:12-13) presumably represent the false shepherds of Israel (Jer 23:1-2; Ezek 34:10), hence might function as the allegorical equivalent (though certainly not with the same function in the story itself) of the thieves and the robbers - those who care about their own office rather than about the sheep" (Gospel of John, 1:812). 
In v. 14, Jesus again refers to himself as the good shepherd, thereby creating a thematic frame:

v. 12: Good shepherd, who lays down his life

v. 13: Hired hand, who abandons the flock

v. 14: Good shepherd, who knows his own

Such framing is intended to highlight the contrast between the good shepherd and the hired hand (or, at another level, between Jesus and the Pharisees). Also returning here is the theme of the shepherd knowing the sheep and vice versa, first alluded to in vv. 3-4, where we witness both the shepherd calling the sheep by name and their response of following because they recognize his voice.

Jesus is the good shepherd because of his relationship with the Father (v. 15a), and this relationship involves a specific mission of laying down his life (viz., subjecting himself to death) on behalf of the sheep (v. 15b). Again, on the surface this sacrifice would appear to leave the flock more vulnerable than ever, but this is not the case; the good shepherd will continue guiding the flock and bringing others into the fold. This is because, as we will see, he has the power both to lay his life down and to take it up again - both of which are not-so-subtle references to the forthcoming crucifixion and resurrection.

Perhaps the most enigmatic statement in the entire discourse is Jesus' claim that he has sheep from another fold that must be brought into the same fold as those who are presumably in his audience (v. 16). As mentioned above, the idea of one shepherd ruling Israel was, by this time, commonplace in Jewish thinking. Jesus extends that traditional idea here by referring to "other sheep" that will be brought over into the same fold. The shared knowledge that characterizes God's covenant relationship to his people is now embodied in the mysterious connections between Father and Son, on one hand, and between Jesus and "the sheep," on the other. ${ }^{40}$ Against that backdrop, Jesus states for a third time in v. 17 that he has the authority to lay down his life, but this time he adds, "and I have the authority to take it up again." Here we have a new affirmation from Jesus. The good shepherd is will-

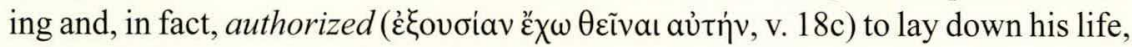

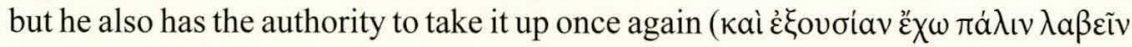
av่⿰ท่v, v. 18d). Beyond Jesus' having the authority to do this, it is actually the command of the Father! Here we have a striking contrast to Jesus' portrayal in the Synoptics. The various Synoptic portraits have Jesus at the mercy of those who would seek his life and further picture him in anguish in Gethsemane, praying that

${ }^{40}$ Covenant is an overlooked theme in the Fourth Gospel; see the insights of Sherri Brown, Gift upon Gift: Covenant through Word in the Gospel of John (Princeton Theological Monograph Series 144; Eugene, OR: Pickwick, 2010); and Rekha M. Chennattu, Johannine Discipleship as a Covenant Relationship (Peabody, MA: Hendrickson, 2005). 
his cup may be taken from him (Mark 14:32-42; Matt 26:36-46; Luke 22:39-46). In the Fourth Gospel, it is clear that Jesus is in control of the situation; he alone holds charge over both the laying down and the taking up of his life. This becomes even clearer in 12:27, in what might be called a reversal of the Gethsemane traditions, where Jesus proclaims, "Now my soul has become troubled. But shall I say, 'Father, save me from this hour?'No, but for this very purpose I came to this hour." Additionally, the language of "laying down" ( $(i \theta \eta \mu)$ and "taking up" ( $(\alpha \mu \beta \dot{\alpha} v \omega)$ is critical to the anticipation of Jesus' death and resurrection in subtle ways throughout the narrative. It will appear again in the raising of Lazarus (see 11:34) and at a critical juncture in the Farewell Discourse (see 13:4, 12) and is evidence of the narrator's continued use of prolepsis to anticipate Jesus' passion and resurrection. ${ }^{41}$

\section{Division over Jesus' Teaching (vv. 19-21)}

This section ends in much the same way as the previous chapter, which concluded with a dispute about Jesus. In 9:40, some of the Pharisees, who are embroiled in a conflict with Jesus, ask him, "We are not blind, are we?" With that question, they correctly apprehend the substance of his comments toward them. Here, however, the dispute is a little more convoluted. Whereas in 9:40 there was a clear division between Jesus and the Pharisees, here we have a division among various

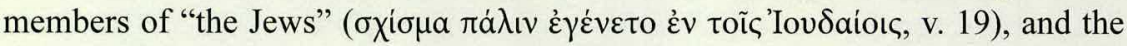

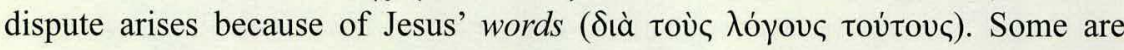
opposed to his teaching, insisting that he has a demon (v. 20), while others rightly object that a demoniac would not be able to open the eyes of a blind man (v. 21). From the perspective of the implied author and in light of the cumulative narrative rhetoric to this point, both reactions reflect an illegitimate response to Jesus. Throughout the story thus far, there has been a continual contrast between those who believe in Jesus on the basis of his word (which is regarded as legitimate Johannine belief) and those who believe in him on the basis of his works (which is rejected as mere signs-faith). ${ }^{42}$ While no one in this section of the text embraces

${ }^{41}$ In 13:4 Jesus will rise from the meal with his disciples, remove his outer garments ( $\underline{\tau i \theta \text { nolv }}$

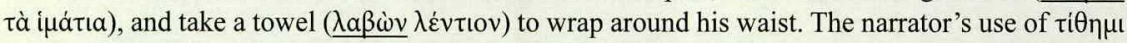
and $\lambda \alpha \mu \beta a \dot{\alpha} \omega \omega$ (there and in 13:12) will call attention back to the image of the good shepherd in

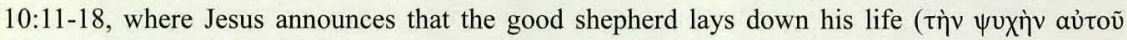
$\tau i \theta \eta \sigma เ v, 10: 11,15,17,18)$ in order to take it back up again (iva $\pi \dot{\alpha} \lambda \iota v \lambda \dot{\alpha} \beta \omega$ av̉ $\eta^{\prime} v, 10: 17,18$ ). The use of $\tau i \theta \eta \mu \mathrm{t}$ will also recall the words of Jesus in 11:34, when he inquires about the burial place of

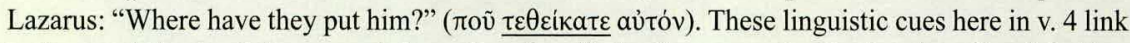
to the good shepherd discourse (where there is veiled reference to the "laying down" and "taking up" of life) and the encounter with Lazarus (where death and burial are explicit).

${ }^{42}$ There is a distinction throughout the Fourth Gospel between those who come to follow Jesus as a result of specific signs they have witnessed and those who follow on the basis of Jesus' word. Those who believe because of Jesus' works either fall away or show that they do not fully understand 
Jesus on the basis of his word(s), some members of "the Jews" in v. 20 reject his words while the latter group in v. 21 seems to be swayed by his works. Neither group responds to Jesus in a way that is considered acceptable in the context of the unfolding narrative christology. The entire group is as blind-at least from the evaluative point of view of the narrator-as Jesus insists they are.

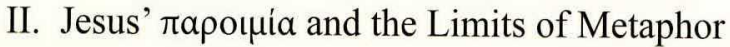

The goal of our exegesis has been both to situate this text in its historical and ideological settings and to provide an interpretation of the various metaphorical elements in Jesus' "figure of speech," all with a view to questioning the legitimacy of specific assertions about the "laying down" of the shepherd's life. Now that we have engaged the text of John 10:1-21 in greater detail, it remains to discuss the extent of both its verisimilitude and its use of metaphor, and to raise the question, Despite the realism of the scene depicted in Jesus' discourse, what are we to make of a shepherd sacrificing his life on behalf of his sheep? When dealing with the Synoptic parables, we are continually forced to ask how far can we press their various allegorical elements. ${ }^{43}$ There is rarely, if ever, a one-to-one correspondence between the figures of a parable and real-world entities, though the parables cannot work without some of their features having such correspondence. Yet to read the parables in a way that insists each symbol corresponds to something in the real world would border on the nonsensical and would repeat some of the mistakes inherent in patristic interpretation of the parables ${ }^{44}$ Similarly, if we treat each metaphorical element of this $\pi \alpha \rho \mu^{\prime} \alpha$ as if it corresponds to a real-world correlative, we

his message, mission, and identity (e.g., Nicodemus 3:1-12; the crowds in chap. 6). On the other hand, those who act on or believe in Jesus' word are the ultimate models of faith and/or faithfulness (e.g., the mother of Jesus in 2:1-11; the woman of Samaria in 4:4-42). This emphasis is perhaps best seen in Jesus' climactic announcement to Thomas in 20:29: "You believe because you have seen [= belief by works]. Blessed are those who have not seen and yet believe [= belief by the proclaimed word]."

43 The question of balance between everyday realism and allegory is an ever-present one in parables research. From the earliest Christian interpreters up to the late nineteenth century, various degrees of allegorical interpretation have won the day. Much of this changed after the publication of Adolf Jülicher's epoch-making work, Die Gleichnisreden Jesu (2 vols.; Tübingen: Mohr, 1888, 1899). For a recent overview of trends in current parables research over the last century, see Ruben Zimmermann, "Gleichnishermeneutik im Rückblick und Vorblick: Die Beiträge des Sammelbandes vor dem Hintergrund von 100 Jahren Gleichnisforschung," in Hermeneutik der Gleichnisse Jesu: Methodische Neuansätze zum Verstehen urchristlicher Parabeltexte (ed. Ruben Zimmermann and Gabi Kern; WUNT 231; Tübingen: Mohr Siebeck, 2008) 25-63.

${ }^{44}$ Perhaps the most notew orthy example of such christological exegesis is Augustine's reading of the Good Samaritan parable (Luke 10:29-37). Throughout his exegesis he engages in highly inventive allegorizing including identifying the man in the parable as Adam, Jerusalem as the heavenly city of peace, the thieves as the devil and his angels, and the innkeeper as the apostle Paul. 
will be guilty of misreading the text. The authenticity of the following elements of Jesus' $\pi$ apout $\alpha$ were discussed in detail above; these can plausibly be established as part of the experience of shepherding in and around first-century Palestine:

1. the existence of an enclosure in which sheep were housed, with or without a door (vv. 1-3)

2. the realistic threat of thieves and robbers (vv. 1, 8, 10)

3. the relationship of the shepherd to the sheep, including his naming of them, their awareness of and attention to his voice, and their following of him on that basis (vv. 3-5)

4. the sheep being startled by the voice of a stranger; their unwillingness to follow a stranger (v. 5)

5. the shepherd lying over the opening of the enclosure and thus literally serving as the door to the sheep pen (v. 7)

6. the realistic threat of attack from predatory animals (in this case, a wolf) (v. 11)

7. the presence of a hired hand to assist with tending the flock (vv. 11, 13)

8. the shepherd knowing his own sheep and their knowing him (v. 14)

Each of these pieces of Jesus' $\pi$ a a first-century audience could have quickly and reasonably related. After carefully considering these details, we can conclude that the scene depicted in the Good Shepherd discourse reflects an authentic situation against the backdrop of our reconstructed knowledge of shepherding in and around first-century Palestine. But it remains to discuss the realism of the shepherd "laying down his life" on behalf of the sheep. While it can be taken for granted that "good" (viz., "competent") shepherds had to be invested in the well-being of their flocks, it does not naturally follow that they would willingly "lay down their lives" for their sheep. On such an interpretation, according to Andrew T. Lincoln, "The life of a shepherd could involve risk or danger, and resisting thieves or wild animals (cf. 1 Sam. 17.34-7) might on occasion lead to a shepherd's death. But defining the good shepherd in terms of his actual death on behalf of the flock goes well beyond all scriptural imagery about the shepherd's relation to the flock." ${ }^{45}$ Since it seems clear that this is the singular element of the discourse that is meant to be taken in a completely metaphorical manner, how does this impact our reading of the Good Shepherd discourse in general and vv. 11, 15, 17 in particular?

First, it is important to remember that one major purpose of the Johannine discourses (e.g., $3: 1-36 ; 6: 22-66 ; 7: 1-52 ; 8: 12-59 ; 13: 1-17: 26$ ) is to allow narrative space for the voice of Jesus to develop the Gospel's unfolding christology.

${ }^{45}$ Lincoln, Gospel according to Saint John, 296 (emphasis added). Lincoln departs from the position taken here and regards the background as related to Greek traditions about honorable death. Nevertheless, his comment is appropriate to our argument. 
There can be little doubt that the metaphorical image of the good shepherd is inherently christological, even if it is meant to connect with the audience at the level of everyday experience. Second, the image of the good shepherd is intro-

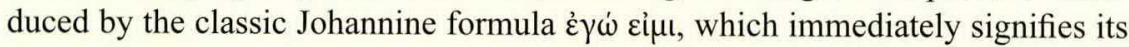

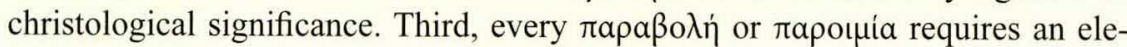
ment with an explanatory power that reaches beyond the realm of the everyday. With most of Jesus' parables in the Synoptics, that element must explain something about the kingdom; here in the Fourth Gospel, that element must explain something about John's unique christology.

From the first recorded day of Jesus' activity (1:19-28), the narrative steadily progresses toward Jesus" "hour" - the moment of his glorification. ${ }^{46}$ The notion of Jesus' hour is related to his mission, which is intimately tied to the Gospel's christology. Jesus is the man from heaven with both the authority and the command from the Father to lay down his life (through crucifixion) and take it up again (through resurrection). The entire narrative is leading to that climactic moment, and the assertion about the shepherd laying down his life in vv. 11, 15, 17 is yet another instance of the evangelist utilizing prolepsis to point the audience ever forward in anticipation of Jesus' glorification.

To conclude, while Jesus' $\pi \alpha \rho \mu_{\mu i} \alpha$ largely reflects the workaday experience of shepherds in and around Palestine in the first century, the intentional laying down of the shepherd's life as a normative expectation would have been both unrealistic and unreasonable. The laying down of the shepherd's life in John 10 is primarily about the imminent reality of Jesus' death rather than the mere risking of his life. As such, this lone affirmation of the Good Shepherd discourse represents a departure from the everyday norms depicted throughout the story and cannot be

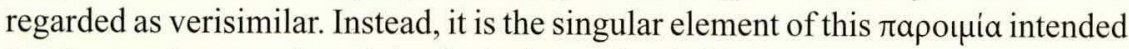
to advance the narrative christological agenda of this discourse.

46 Jesus' "hour" (ळ̋ narrative; see, e.g., $2: 4 ; 4: 21,23 ; 5: 25,28 ; 7: 30 ; 8: 20 ; 12: 23,27 ; 13: 17$. For a detailed exposition of this critical theme in the Fourth Gospel, see the chapter entitled "The Hour Has Not Yet Come" in Francis J. Moloney, Love in the Gospel of John: An Exegetical, Theological, and Literary Study (Grand Rapids: Baker Academic, 2015) 71-98. 
Copyright of Catholic Biblical Quarterly is the property of Catholic Biblical Association of America and its content may not be copied or emailed to multiple sites or posted to a listserv without the copyright holder's express written permission. However, users may print, download, or email articles for individual use. 